\title{
China's Development Banks in Asia: A Human Rights Perspective
}

\author{
Matthias Vanhullebusch
}

\section{Introduction}

China's economic and financial trajectory has entered a new phase in its overseas development agenda. Since the establishment of the New Development Bank, also known as the BRICS-bank in 2014, and the Asian Infrastructure Investment Bank (AIIB) in 2015, China's relationship with its regional counterpart, i.e. the Asia Development Bank of which it is a member since 1986, has been redefined. China's efforts to reshape the international economic order in its own image inevitably affect its development and normative discourses as well as strategic partnerships through those financial institutions. Pursuant to China's 2015 Vision and Actions on Jointly Building Silk Road Economic Belt and 21st-Century Maritime Silk Road, their creation is inextricably connected with China's geopolitical ambitions to foster economic and development relationships with the nations on its Silk and Maritime Roads towards a community of common development. ${ }^{1}$

China's reassurances however regarding the complementary rather than competing role of its financial vehicles vis-à-vis other development banks have not

Series Editor of Brill's Asian Law Series and the Routledge Studies on Asia in the World.

${ }^{1}$ People's Republic of China, Chinese National Development and Reform Commission, Ministry of Foreign Affairs, and Ministry of Commerce (2015). See also Zeng (2016), Ingram and Poon (2013), Griffith-Jones (2014), Schablizki (2014), Abdenur (2015), Abdenur and Folly (2015), pp 66-95, Bob (2015), Griffith-Jones (2015), European Political Strategy Centre (2015), Renard (2015), Callaghan and Hubbard (2016), pp 116-39, Etzioni (2016), Wan (2016).

M. Vanhullebusch ( $\square)$

KoGuan Law School, Shanghai Jiao Tong University, Shanghai, China

e-mail: matthias.vanhullebusch@gmail.com

M. Vanhullebusch

School of Oriental and African Studies, University of London, London, UK

(C) The Author(s) 2018

Y. Nakanishi (ed.), Contemporary Issues in Human Rights Law,

DOI 10.1007/978-981-10-6129-5_10 
entirely convinced Western nations to disregard China's underlying sovereign agenda. Particularly, concerns have been raised in respect of the standards adopted by those new banks in screening, evaluating and monitoring projects/proposals and granting funds for certain investments in Asia. Therefore, environmental benchmarks and labour conditions would be seen as compromised. Conversely, the West's international standards and conditionalities would better protect the livelihood of national and local communities instead. Nonetheless, such attitudes can be an overture for a broader dialogue between those established and new financial development institutions to gradually negotiate and internalize common standards especially given the mixed membership of the AIIB. ${ }^{2}$

Besides such potential grounds for cross-fertilization of human rights norms and strengthening of cooperation agendas across those different development banks, the protection of socio-economic and environmental rights by China's development banks must be conceived in light of its understanding of the developing countries' right to development in the first place. In addition, China's commitment to pursue its rule of law reforms domestically has immediate repercussions upon its international image as well as its resolve to abide to international law in particular in the field of human rights and development. Yet, such adherence has to be contextualized and, as a result, the implementation of human and environmental rights by virtue of the financial practice of China's development banks overseas will be progressive. $^{3}$

This paper will examine those various human rights concerns in China's new multilateral development banks operating within Asia and beyond. It will firstly address how those financial institutions have been justified from the Chinese perspective. It will particularly focus on how the so-called right to development has given legitimacy to China's New International Economic Order by means of the establishment of its own financial development institutions. Secondly, it will contextualize and scrutinize China's past and present contributions to existing multilateral development banks and evaluate how - in spite of its promises towards complementarity of its new institutions-whether such contributions may effectively advance a multilateral and cooperative approach towards financing development in Asia. Thirdly, this paper will examine the prospects for the respect of environmental and social standards in the financing of development initiatives through China's new multilateral development institutions and the possibilities to further coordinate with other regional and global development institutions in the creation, development, interpretation and application of such human rights benchmarks that are fit to guide the financing of development efforts in Asia.

\footnotetext{
${ }^{2}$ Chen (2013), Lagon and Nowakowski (2015), Ito (2015), Subacchi (2015), Coalition for Human Rights in Development (2016), Evans (2016), Rosenzweig (2016), Sharda (2016).

${ }^{3}$ See more UN Guiding Principles on Foreign Debt and Human Rights (2011), Acharya (2011), pp 95-123, Griffith-Jones (2012), Ruskola (2013), Bohoslavsky (2015).
} 


\section{The Right to Development: Giving Legitimacy to China's New International Economic Order}

While the right to development was once invoked to emancipate peoples in the aftermath of their struggles for independence against colonialism in various parts of the world ever since the 1960s to bolster their additional claims for a restructuring of the international economic order - as once confirmed with the adoption of the UN General Assembly's Declaration on the Establishment of a NIEO ${ }^{4}$ as well as the Charter on the Economic Rights and Duties of States in the early 1970s (those are non-binding instruments or so-called soft law), ${ }^{5}$ the right to development had equally become a tool for developed nations to reconnect with and potentially continue to pursue their economic and political dominance vis-à-vis the least fortunate members of the international community yet under the veil of solidarity and development assistance-either through financing development and preferential trade. The latter intervention - in violation of Article 2(7) of the UN Charter-had moved the collective right of development-as once an expression of the peoples' right of self-determination ${ }^{6}$-into the realm of individual human rights protection. In this regard, from the late 1970s onwards, the UN Human Rights Commission and UN General Assembly recognized the dual nature of the right to development, namely one that favours the prerogatives of the state - the entity representing the people - on the international plane and the individual within the domestic order. ${ }^{7}$

From a textual perspective, though, such evolution appears to be in conformity with the UN Charter and the international obligations that are imposed upon all UN member states in respect of Chapter IX on International Economic and Social Cooperation. Indeed, the commitment to improve human rights-social and economic alike - could eventually lead to "higher standards of living, full employment, and conditions of economic and social progress and development". 8 The premise of the realization of such human rights agenda on behalf states and the international community is based on the notion of the universal respect of individual human rights to which all human beings are entitled to without discrimination. ${ }^{9}$ As far as the division of responsibilities is concerned to fulfil such objectives, the UN

\footnotetext{
${ }^{4}$ N GA Res. 3201/2 (S-VI), UN Doc. A/9559 of 1 May 1974.

${ }^{5}$ UN GA Res. 3181 (XXIX), UN Doc. A/RES/29/3281 of 12 December 1974.

${ }^{6} 1966$ International Covenant of Economic, Social and Cultural Rights (ICESCR), Article 1:

"All peoples have the right of self-determination. By virtue of that right they freely determine their political status and freely pursue their economic, social and cultural development.

All peoples may, for their own ends, freely dispose of their natural wealth and resources without prejudice to any obligations arising out of international economic co-operation, based upon the principle of mutual benefit, and international law. In no case may a people be deprived of its own means of subsistence."

${ }^{7}$ UN Commission on Human Rights, Res. 4 (XXXIII) of 21 February 1977; UN GA Res. 34/46, UN Doc. A/RES/34/46 of 23 November 1979.

${ }^{8} 1945$ UN Charter, Article 55(a).

${ }^{9}$ Ibid., Article 55(b).
} 
General Assembly's 1986 Declaration on the Right to Development firstly located such with the state on whose territory such human rights are claimed and secondly with the other members of the international community. ${ }^{10}$ In practice, however, developing countries - in the interest of their economic and political priorities (domestic and international alike) - have undermined the protection of such human rights and fundamental freedoms under the pretext of the collective nature of the right to development. ${ }^{11}$ Conversely, developed nations in their political and economic relations with the former have introduced human rights conditionalities in their trade negotiations to prevent an erosion of the state's primary responsibility to uphold those rights.

Such strategies and institutionalization of human rights protection on behalf of developed vis-à-vis developing nations have further eroded the earlier consensus that once reigned over the dual nature of the right to development and moved the latter back into the policy realm, namely where either defensive or rather assertive claims of developing countries could be advanced to question the veracity of the underlying values that would underpin the so-called new international economic order as it has evolved in the meantime since the end of colonial era. The lack of trust on both sides of the divide has further exacerbated since the global financial crisis of 2007-2008 that had hardly hit the socio-economic conditions of the peoples in both developing and developed countries. The latter's decreasing political and financial commitment to advance human rights protection either through trade and development assistance has changed their geopolitical role. While some new emerging economies had dramatically improved the socio-economic well-being of their peoples, broader discussions on the fulfilment of individual human rights entitlements had not come to fruition within those nations and had made it even more difficult on the longer term to seek a better understanding on both sides to engage in a fundamental human rights dialogue and cooperation that was once envisaged under the UN Charter and consecutive UN General Assembly resolutions.

The problem of leadership and ownership over individual human rights discourses would inevitably rebut claims that hegemonic economic aspirations under the veil of human rights entitlements were ever possible and eventually may reinforce the view of a (cultural) relativist approach to human rights protection in the first place. Those developments are paralleled by a similar division within the realm of international trade negotiations where mutual suspicion about the other's sovereign agendas has further fragmented trade relationships into regional initiatives, including the former Transpacific Trade Partnership (TTP), the (forthcoming?) Transatlantic Trade and Investment Partnership (TTIP), the forthcoming Regional Economic Comprehensive Partnership (RCEP), and even towards more protectionist attitudes as testified particularly in Western nations. How then to (re)connect again and seek cooperation regarding human rights protection in the

\footnotetext{
${ }^{10}$ UN GA Res. 41/128, UN Doc. A/RES/41/128 of 4 December 1986.

${ }^{11}$ See more Cunliffe (2007), p. 40.
} 
socio-economic realm at the international level when universal rules are giving way for more regional perspectives in particular in the economic field?

In this respect, China's attitude towards economic governance appears to depart from the traditional/Western rule-based international order and has enabled it to profile itself economically and politically in a stronger position as opposed to Western nations that have been self-absorbed in regulating international life through international norms in the socio-economic and human rights arenas. For those reasons, China's relational governance focuses predominantly on the relationships between regional and global actors in various fields. According to Qin Yaqing who developed a theory on relationality - as grounded in a Chinese epistemology — and applied onto China's normative behaviour on the international scene, relational governance aims to create order in an ever-changing international economic and political environment. Furthermore, such understanding of "process of negotiating socio-economic arrangements that manage complex relationships in a community to produce order so that members behave in a reciprocal and cooperative fashion with mutual trust evolved over a shared understanding of social norms and human morality", ${ }^{12}$ as Qin defines relational governance, can produce valuable insights in how the current state of economic relations and correlative commitment in the realm of development cooperation to advance the livelihoods of human beings regionally and internationally alike has evolved over the course of time and in space.

This relational governance approach further postulates that "rules, regimes, and institutions are not established to govern or restrain the behavior of individual actors in society, but to harmonize relations among members of society". ${ }^{13}$ If one then projects the discontent that mutually governs the relationship between developed and developing countries who respectively defined the right to development as too narrow or broad onto this approach of relational governance, one can notice that China has sought to (re)establish trust not on the mere ground of a common definition around a number of international obligations-on which developed and developing countries fundamentally differ (see discussion on the dual nature on the right to development)_-but on the basis of general principles of international relations and law instead. In this regard, China's Five Principles of Peaceful Coexistence - which include mutual respect for sovereignty and territorial integrity, mutual non-aggression, non-interference in each other's internal affairs, equality and mutual benefit and peaceful coexistence - share an important common denominator with other international norms, including the UN Charter and in particular - for the purpose of the discussion before us - in the field of international economic and social cooperation. Thus, Chapter IX of the UN Charter, Article 55in its chapeau, makes clear reference to the purpose of such cooperation, namely "with a view to the creation of conditions of stability and well-being which are

\footnotetext{
${ }^{12}$ Qin (2011), p. 133.

${ }^{13}$ Qin (2010), p. 138.
} 
necessary for peaceful and friendly relations among nations based on respect for the principle of equal rights and self-determination of peoples".

As a result, the principle of sovereign equality, mutual benefit and peaceful coexistence can be read together and, accordingly, must govern the relationship so that cooperation and process in this important field can be achieved over the course of time and in space. Respect for those fundamental principles can facilitate on the long-term the restoration of trust in the conflictual relationship between developed and developing countries. Indeed, one the basis of mutual benefit, China has repeatedly argued that such is a prerequisite in its economic and political relationship with its economic and strategic partners. On its turn, this can bring the right to development again to the foreground since it will focus on its policy application rather than human rights connotation in order to establish economic relationships in the first place. Yet, an opening towards a rule-based governance approach remains possible and desirable once the content of the right to development has been properly defined on the basis of sovereign equality too. In this respect, the meaning of the right to development, from the Chinese perspective, is derived from the relationship between the respective international/regional actors that can give content to its rule-both in its collective and individual dimensions. Since that meaning still differs-depending on developed and developing countries, a principle-based approach may transcend such fundamental differences and give sufficient room for trust to gain ground once developing countries are ready to advance individual human rights entitlements in the socio-economic realm. ${ }^{14}$

This approach of relational governance has been clearly manifested in China's 2003 position on establishing a New International Political and Economic Order. The Five Principles of Peaceful Coexistence should constitute the basis for cooperative relationships between developed and developing nations. Differences between the national conditions should not be an obstacle to establishing inter-state relationship nor constitute a reason for intervention in the domestic affairs of states. Instead, countries "should cooperate with one another on the basis of equality and mutual benefit to realize common development. The old irrational international economic order should be reformed to serve the rights and interests of the countries of the world, especially the numerous developing countries". 15 Paradoxically enough, irrational and nationalist claims for protectionism across Western nations have similarly been denounced by the Chinese leadership, in particular recently by President Xi Jinping, since it would deny that a relationship could no longer be fostered whenever there is collision or a divergent opinion on socio-economic policies amongst the diverse members of the international community. ${ }^{16}$

\footnotetext{
${ }^{14}$ See Vanhullebusch (2014), p. 226.

${ }^{15}$ China's Position on Establishing a New International Political and Economic Order (18 August 2003).

${ }^{16}$ Speech of President Xi Jinping at the World Economic Forum Annual Meeting (2017). Some have argued that China's call for a global liberal order departs from its domestic take on liberal dissent. See The Economist (2017).
} 
Therefore, China's approach on an international economic order would inevitably take into account the inherent positive and negative characteristics of any economic relationship between actors on the international plane that over the course of time can change towards mutual benefit and common development as its 2011 White Paper on Peaceful Development indicated. ${ }^{17}$ China however had for a long-time asserted that it was not willing to assume a leadership role or represent the developing countries in establishing such new order given its historic anti-imperialist claims against any hegemonic ambitions in particular in light of its own historical experience with Japan in the past and with the US - until more recently. The erosion of the latter's global leadership-involuntary (since the Clinton administration) and willing (since the Trump administration) alike- has, arguably, put China on the spot to assume greater responsibilities in this respect as was testified in the speech of Xi Jinping in Davos at the World Economic Forum on 17 January 2017.

Regionally however such role has been feared by regional and international actors alike. China has been particularly cautious about its initiative to steer a regional economic order in its image. Rather than focusing on a particular regional order in Asia, China has since 2013 - with the ascent to power of Xi Jinping, projected and represented its One Belt One Road policy as a historical renaissance of all Asian nations'—not exclusively China's_-past economic relationships along the continental and maritime Silk Roads. Subject to the suspicion of smaller nations (in particular those involved in the maritime disputes in the South China Sea) and of larger nations (including India and Japan), China has tried to convince Asian countries to reconnect to those roads and presented the project as an Initiative instead giving sufficient room for those countries to cooperate, give input and mutually benefit on the basis of sovereign equality. ${ }^{18}$

While China may be able to shape the new international economic order and its Asian regional Silk Road Initiatives on the basis of its Five Principles of Peaceful Coexistence, in particular sovereign equality, non-interference into the domestic affairs of state and mutual benefit - each of which are reflective of its own anti-hegemonic discourse, and receive support given the aspirations of common development in pursuit of the right to development of all nations - developed and developing alike, China's role and contribution to that effect may still suffer from legitimacy for a number of reasons. Regarding China's geo-economic ambitions, the trade deficit of China's economic partners has consumed much of their internal discussion on how to redefine their trade and political relationship respectively with China in general and the Communist Party of China in particular. Furthermore, China's outbound foreign investment and acquisition of overseas crucial industries -from agricultural, chemical, infrastructure, IT, mining and pharmaceutical sectors to shipping - have added more fuel to the protectionist anxieties reigning in Western countries. Vis-à-vis developing nations in Africa, Asia and Latin America

\footnotetext{
${ }^{17}$ State Council of the People's Republic of China (2011).

${ }^{18} \mathrm{Xi}$ (2014), pp 315-19.
} 
alike, China's strong presence in infrastructure projects in those countries as well as their dependency on the supply chains of raw materials and parts to China's manufacturing base have equally raised concerns about the consequences and dominance of China's economic agenda upon the internal affairs of those nations states. Nonetheless, China's large investment in its own national economy during the financial crisis of 2007-2009 has prevented those trading partners to suffer even more from the global economic downturn.

Those external conditions have put increasing pressure on the principle of sovereign equality. Moreover, China's internal decision-making in the economic and political realm has casted additional worries on how this may affect the relationship with the other members of the international community and the prospects to restructure the international and regional economic orders. In this regard, corruption within Chinese society and government has severely damaged its domestic and international image. While the Chinese top leadership - ever since the ascent to power of Xi Jinping in 2013 - has fought corruption at all levels and within all sectors of economic and political life in China through populist purging, it remains to be seen whether this will eventually lead to better and more accountable governance within China in the first place and whether it was purely aimed to consolidate the power into the Chinese presidency instead. These domestic developments towards the rule of law inherently affect the credibility of China on the international plane and in its ability to assume its power responsibly in the realization of its trade and development goals with its political and economic partners within its neighbourhood, the region and the world at large. It is against this background that one must see in the following section how China has over the course of time participated in other international and regional multilateral development banks and how it aims to gain confidence and uphold its legitimacy when building its own institutions that are geared towards financing trade and development within Asia and beyond for the sake of common development.

\section{Finance, Development and China: From Participation to Institution-Building}

Traditionally, China has been a reluctant participant in international institutions that, in its view, would limit its sovereign interests. Given its exclusion from the UN since the establishment of the People's Republic of China on 1 October 1949due to the representation by the Taiwan government as the sole representative of the Republic of China instead - until its reinstatement on 25 October $1971,{ }^{19}$ it would take a considerable amount of time before China would find mutual benefits in cooperating with the UN on the one hand and other international and regional institutions in particular multilateral development banks on the other hand. Yet, its

\footnotetext{
${ }^{19}$ UN GA Res. 2758 (XXVI), UN Doc. A/RES/26/2758 of 25 October 1971.
} 
original concerns regarding the architectural design and operationalization have remained in place until the present day. China has vehemently opposed the use of those institutions to serve the so-called hegemonic interests of the world superpowers, the US and the USSR, during the Cold War and their instrumentalization on behalf of the US in defiance of the existence of a multipolar world after the Cold War that would keep developing countries within a subordinate political, socio-economic, financial and development position. To that effect, the World Bank was seen as the primary example of such old international economic order that was once established after World War II to serve as financial vehicles of Western nations to suppress developing countries in violation of the principle of sovereign equality.

Nonetheless, from the 1980s onwards, China did-since its economic opening-up in 1978 - find interest to join the World Bank not only to gain funds in the first place but also later onwards to become an important lender for development projects in other parts of the world. While China was originally a founding member of the bank, its rights were restored when the Executive Board of the World Bank approved its representation at the Bank on 15 May 1980. Ever since, China has strengthened its relations with the Bank and has become a more mature partner in development financing. In this regard, when China marked its 30th anniversary membership in the World Bank, it had assumed more responsibilities in particular as a contributor to the International Development Association-a part of the World Bank Group that supports the poorest nations with low interest loans. China's own economic development had given it sufficient resources to fund such initiatives within the World Bank.

Therefore, China has repeatedly advocated in favour of a balanced representation of the shareholders at the World Bank which required a reform of the voting power system and a reorganization of the management structures. ${ }^{20}$ When developed and developing countries share their voting power equally, a recalibration of their relationship that removes distinction and thus discrimination through such institutional intervention could reconcile contradiction between those different members in the operationalization of the World Bank's activities and the negotiation processes that affect its decision-making on the basis of sovereign equality. ${ }^{21}$ By promoting reform, the relationships between the members of the World Bank have become more democratized and the internal functioning and environment of the World Bank could create more stability and hence a better prospect to fulfil its essential mandate. As of 13 January 2017, China has $4.60 \%$ of the voting power within the International Bank for Reconstruction and Development while it retains $4.84 \%$ of the total subscription of shares where its ranks third after Japan $(7.12 \%)$ and the US (16.47\%). ${ }^{22}$ Although China still has a disproportionate impact as

\footnotetext{
${ }^{20}$ International Division of Ministry of Finance of the People's Republic of China (2011), pp 132133.

${ }^{21}$ Worldbank.org (2010).

${ }^{22}$ Worldbank.org (2017).
} 
opposed to those Western nations, China has sought to use the World Bank to disseminate its own development experience to other developed and developing countries with a view to establishing trust within this multilateral setting. In this respect, China had successfully reduced poverty at home, namely the proportion of poor people in China's rural areas reduced form $73.50 \%$ in 1990 to $7.20 \%$ in 2014 which contributed to more than $70 \%$ of the total of global poverty reduction in that

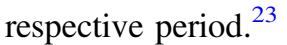

China has also participated as a non-regional member in a number of other regional multilateral development banks. In this regards, China joined the African Development Bank in $1985,{ }^{24}$ the Asian Development Bank in $1986,{ }^{25}$ the Caribbean Development Bank in $1998^{26}$ and the Inter-American Development Bank in 2009. ${ }^{27}$ Here too, in more recent years in particular during and in the aftermath of the global financial crisis of 2007-2008, China has tried to show-case its developmental trajectory in the proposals for financing development projects in numerous sectors including energy, infrastructure, agriculture, health care, education, training, etc. in order for those developing countries to become in the end economically more self-reliant - this in line with the collective meaning of the right to development, namely to dispose of one's own natural wealth and to determine one's economic policy (more) independently. At the same time, it has also aimed to put the democratization of the multilateral development banks in Latin America and Asia on the agenda and to reform those institutions accordingly. Reducing the dominance of the US in the Inter-American Development Bank $(30 \%)$ and of Japan (15.6\%) and the US (15.5\%) in the Asian Development Bank could, from the Chinese perspective, restore trust between the developed and developing countries, confidence in the respective banks to fulfil their mandates and enhance South-South cooperation as well as regional integration. ${ }^{28}$

Needless to say that China's bilateral aid with nations accounts for the majority of its development and financial aid. As opposed to channelling financial support through multilateral international and regional development vehicles/banks, China has found that its bilateral approach has been more efficient and effective when its boils down to the implementation of its development projects. Development aid granted by multilateral development banks may also suffer from such transparency and sustainability as a result. ${ }^{29}$ Furthermore, most development banks are dominated by developed nations and China inevitably can exercise limited influence under those mechanisms. Given the latter's composition, China has been cautious about the hidden geopolitical and other hegemonic narratives that drive the

\footnotetext{
${ }^{23}$ United Nations (2015).

${ }^{24}$ Afdb.org (2017).

${ }^{25}$ Adb.org (2017).

${ }^{26}$ Caribank.org (2017).

${ }^{27}$ Iadb.org (2008).

${ }^{28}$ Ministry of Foreign Affairs of the People's Republic of China (2006), Xie (2008).

${ }^{29}$ Brautigam (2011), pp 203-22.
} 
operationalization of such Western-dominated development banks in the first place. Therefore, China remains convinced that bilateral relationships in the realm of financing development projects are the most suitable way to establish friendly relationships and cooperation between nation states - in accordance with the spirit of Chapter IX of the UN Charter.

In this regard, China's establishment of the New Development Bank in 2014 and the AIIB in 2015 must been seen in this light. Pursuant to its relational governance, the focus on institution-building and its far-reaching (hegemonic) effects on behalf of some commentators could not be the only purpose and source of China's legitimacy. Instead, those institutions would be there to harmonize the relationship between the members of the respective multilateral development banks in addition to the bilateral relationships amongst them, including with China. Certainly, the departure of those institutions from the inherent imbalance between the respective shareholders and founding members have been a cause of anxiety amongst numerous Western and Asian nations that fear that those development banks would be equally instrumentalized by China to advance its geopolitical and -economic interest within its neighbourhood, the region, along the Silk Roads and the world at large. The internationalization of the Chinese Yuan could arguably be another manifestation of such ambitions, namely to compete with the US Dollar and other Western currencies ever since the International Monetary Fund added the RMB to the basket of Special Drawing Rights (from 1 October 2016 onwards). ${ }^{30}$ Ongoing currencies wars may add further fuel to such suspicions and as a result those financial vehicles would be a source of conflict rather than cooperation.

Yet, according to the Preamble of the Agreement which established the New Development Bank on 15 July 2014, the parties to the Agreement-Brazil, India, China, Russia and South Africa-have a clear desire to strengthen and deepen their economic cooperation and are determined to use the Bank as a development and policy tool to help other emerging economies and developing countries to give access to financial support which in the current system is denied-especially in light of the financial constraints of international institutions which are experiencing budget cuts from the Western members in the aftermath and a result of the financial, economic and budgetary crises in Western countries. The New Development Bank intends to fill those infrastructure gaps from now onwards. ${ }^{31}$ The powers of the Bank however - at least in its present constitutive treaty-do not intend to be competitive to the existing financial and development instruments of other regional and multilateral institutions but rather want to complement those existing efforts and fill the gaps where necessary. On first sight, the financial contributions do not seem to suggest a strong impact upon new development projects - only an initial subscribed capital of US\$ 50 billion and an initial authorized capital of US\$ 100 billion are at its disposal. The initial subscribed capital shall be equally distributed amongst the founding members (Article 2). Nonetheless, the New Development

\footnotetext{
${ }^{30}$ Imf.org (2016).

${ }^{31} \mathrm{Ndb}$.int (2016).
} 
Bank's membership - pursuant to the same Article 2-is open to all members of the UN. An increase of members will necessarily augment the capital of the bank and the means at its disposal to invest in development projects. The structure of the New Development Bank is thus built on the principle of sovereign equality where the five founding member countries have equal voting rights. According to Article 6 of the Agreement, an increase of membership shall proportionality affect the voting power of each member that is dependent on its subscribed shares in the total capital stock of the New Development Bank.

Important in terms of fair representation of membership, a (new) member of the Bank may send a representative to attend any meeting of the Board of Directors when a matter especially affecting that member is under consideration. Such right of representation shall be regulated by the Board of Governors (Article 12i). In a similar vain, in order to ensure independence, the Bank, its officers and employees shall not interfere in the political affairs of any member, nor shall they be influenced in their decisions by the political character of the member or members concerned. Only economic considerations shall be relevant to their decisions, and these considerations shall be weighed impartially in order to achieve the purposes and functions of the Bank as states Article 13 of the Agreement.

The Articles of Agreement signed by the 57 founding members ${ }^{32}$ of the AIIB on 29 June 2015 have laid down similar guarantees as to the cooperative intentions of the new bank with other "multilateral and bilateral development institutions" (Article 1). In this respect, President Jin Liqun of the Bank reassured that the "AIIB appreciates ADB's [i.e. Asian Development Bank] support in this formative phase of its development. We look forward to working together with ADB and other development partners to deliver timely and efficient financing to meet critical infrastructure demand in the Asia Region."33 The initial authorized capital is US\$ 100 billion (Article 4) which may be increased subject to the decision of the Board of Governors but without "reducing the percentage of capital stock held by regional members below seventy-five (75) per cent of the total subscribed capital stock, unless otherwise agreed by the Board of Governors by a Super Majority vote" (Article 5). China however remains the biggest shareholder (33.4\%) and has the most voting power $(28.7 \%)$ of all members of the Bank. ${ }^{34}$ Pursuant to Article 31 of the Agreement, the Bank shall further respect the principle of non-interference into the domestic affairs of states and only take into account economic parameters in its decision-making processes in order to uphold its impartiality and carry out its

\footnotetext{
${ }^{32}$ Aiib.org (2016a).

${ }^{33}$ Jin (2015).

${ }^{34}$ The 57 signatory countries include: Australia, Austria, Azerbaijan, Bangladesh, Brazil, Brunei, Cambodia, China, Denmark, Egypt, Finland, France, Georgia, Germany, Iceland, India, Indonesia, Iran, Israel, Italy, Jordan, Kazakhstan, Kuwait, Kyrgyzstan, Laos, Luxembourg, Malaysia, Maldives, Malta, Mongolia, Myanmar, Nepal, Netherlands, New Zealand, Norway, Oman, Pakistan, Philippines, Poland, Portugal, Qatar, Republic of Korea, Russia, Saudi Arabia, Singapore, South Africa, Spain, Sri Lanka, Sweden, Switzerland, Tajikistan, Thailand, Turkey, UAE, United Kingdom, Uzbekistan and Vietnam.
} 
essential mandate in accordance with the purposes and functions of the Bank as described in Articles 1 and 2 of the Agreement in the first place.

\section{Financing Development in Asia: A Prognosis on China's Human Rights Benchmarks}

From the perspective of relational governance we have thus far observed that China's participation in existing and institution-building of new multilateral development banks in pursuit of its right to development on the basis of sovereign equality and for the purpose of mutual benefit and common development had led to uncertainties regarding the consequences for the normative and operational principles that govern the activities of China's new financial development vehicles. Fears for an erosion of universal human rights standards in the realm of labour and environmental protection would as a self-fulfilling prophecy become a reality if indeed the right to development in its collective dimension would overturn those existing standards. A relativist take on behalf of China and other developing countries may from such perspective underscore the ongoing erosion of international law towards a greater fragmentation of international norms as equally witnessed in the realm of trade affairs.

While precaution must be taken that relational governance trumps rule-based governance in an absolute manner, one should also try to better understand why such approach could effectively contribute to a stronger normative framework that could potentially be more universally accepted by means of regional practices in the long-run. Moreover, it would be wrong to suggest that leadership and ownership over human rights discourses must be defended by Western and/or developed nations alone. Instead, such biases must be transcended. It is submitted that the theory on relational normativity of international law (TORNIL) ${ }^{35}$ could merge a relational and rule-based governance approach that could fit the realities faced by the New Development Bank and the AIIB when funding development projects in cooperation with the World Bank and other regional multilateral development banks, including the Asian Development Bank. This theory argues that without a fertile soil, international norms - in particular human and environmental rightscannot gain root.

In this regard, as a means to enhance the normativity of such norms, relational governance plays a crucial role to establish long-term trust whereby socio-economic arrangements can be found on the basis of a negotiated process where all stake- and shareholders (decision-makers, recipient states and local communities alike) have a common understanding about the norms and morality that equally underpin the normativity of such norms in the first place. The ultimate goal would be to reach a synthesis in the interpretation and application of certain human rights and

\footnotetext{
${ }^{35}$ See more Vanhullebusch (2016a), pp 307-348.
} 
environmental standards, yet the complex processes towards such objective may take a considerable amount of time and must inevitably take into various contextual parameters that inform such outcome. While such result cannot be immediately achieved and nor could the very process be described as being tangible, the very membership of, communication, interaction, dialogue and exchange between developed and developing countries in international and regional multilateral development banks as well as on a bilateral basis can keep the relationship alive, improve it, restore it and move it to a next level once the conditions are right so that international standards may effectively resort effect within different regions.

Before we discuss how such relationships within the AIIB can underpin the normativity of human rights and environmental standards within such regional setting, we'll briefly focus on how China in its domestic jurisdiction imposed a number of responsibilities upon the banking sector in incorporating labour and environmental rights in their financial policies and activities. From 1995 onwards, the People's Bank of China and the State Environmental Protection Administration respectively issued their "Announcement on Credit Policy for Environmental Protection" and "Announcement on Making Use of Credit Policy for Promoting Environmental Protection". In reality, the national economic growth targets however have often trumped those measures. Nonetheless, the National Development and Reform Commission, the People's Bank of China and the China Banking Regulatory Commission issued another statement in 2004, namely the "Announcement on Further Strengthening Industrial Policy and Credit Policy to Control Credit Risks". The annex to this document restricted and banned different polluting industries. In 2005 and 2006, the State Council respectively adopted the "Regulation on Accelerating Adjustment of Industrial Structure" and the "Announcement on Accelerating Adjustment of Industrial Structure with Excess Capacity". They only restricted loans for those projects that suffered from heavy pollution. The financial industry was not provided with any guidance nor imposed specific duties to assume due diligence in granting and monitoring loans and to identify environmental hazards. ${ }^{36}$ Nonetheless, the Ministry of Environmental Protection adopted in 2007 its first real "Green Credit Policy" which accounted for environmental standards in bank lending. The China Bank Association further advanced such measures in its voluntary codes of conduct ever since 2009. Those "Guidelines on Corporate Social Responsibility for the Chinese Banking Sector" demanded from banks to assume social and environmental responsibility at a time when China was gearing its industrial policies towards innovation in the first place. $^{37}$

In terms of its international climate commitments, in September 2016-prior to the G20 Hangzhou meeting in the same month - China together with the US have also ratified the Paris Agreement which was earlier on adopted within the UN Framework Convention on Climate Change in December 2015. Prior to the

\footnotetext{
${ }^{36}$ Bai et al. (2014), pp 105-106, Aizawa and Yang (2010), pp 119-144.

${ }^{37}$ Vanhullebusch (2016b), p. 176.
} 
assumption of power of the Trump administration on 20 January 2017, Chinese negotiators of this climate deal had already shown evidence to take a leading role in the fight against climate change which on its turn would improve China's domestic environmental goals but also its international image accordingly. ${ }^{38}$ How can then China's domestic financial practices and international environmental obligations reassure developed countries - in particular Western members of the AIIB - of the future observance of human and environmental rights standards in the operationalization of China's new multilateral development banks?

Unlike the New Development Bank that doesn't have thus far any reference to such standards, the AIIB to that effect claims to be committed as evidenced both in its Articles of Agreement that established the Bank in June 2015 as well as the later adoption of its Environmental and Social Framework in February 2016. In this regard, pursuant to Article 13 of the Articles of Agreement, the "Bank shall ensure that each of its operations complies with the Bank's operational and financial policies, including without limitation, policies addressing environmental and social impacts". The Environmental and Social Framework gives a very detailed overview of the purposes of taking into account such standards in the Bank's operational and financial policies regarding the evaluation, granting and monitoring of development projects in close cooperation with other multilateral and bilateral development banks, client states, private actors and local communities. ${ }^{39}$ The Bank is particularly concerned about the so-called "operational and reputational risks of the Bank and its shareholders in relation to Projects' environmental and social risks and impacts". 40

In the fulfilment of its mandate, namely to support interconnectivity by means of infrastructure investments in order to boost economic growth and the livelihood of Asian people, the Bank seeks to integrate in a balanced manner the economic, environmental and social dimensions of the new UN Sustainable Development Goals in all its activities. ${ }^{41}$ The Environmental and Social Framework further outlines each of those dimensions. Firstly, regarding environmental standards, the Bank is committed to support the aims of the Paris climate deal of December 2015 when financing its client states to achieve their NDCs (nationally determined contributions), "including through mitigation, adaptation, finance, technology transfer and capacity-building". ${ }^{42}$ Secondly, in respect of the protection of labour rights, the Bank regards that the protection of the workers in their essential contributions to the sustainable growth in Asia in itself constitutes a guarantee for the quality of the projects that are funded by the Bank in the first place. As a result, proper wages, sanitary and safe working conditions, prohibition of forced/child labour, proper human resources management, non-discriminatory treatment of

\footnotetext{
${ }^{38}$ Volcovici and Wong (2011).

${ }^{39}$ AIIB Environmental and Social Framework, paras 21, 33.

${ }^{40}$ Ibid., preamble.

${ }^{41}$ Ibid., para 7.

${ }^{42}$ Ibid., para 16.
} 
workers, freedom of association, collective bargaining and access to complaint mechanisms should be in place to ensure the workers' conditions in those projects financed by the Bank. Evidently, the implementation of such sustainability goals by the recipient nation and their evaluation on behalf of the Bank must be balanced too and thus take into account how such norms are consistent with the national law of the client state and thus in respect of the principle of sovereign equality of states and non-interference in the domestic affairs of states - in particular into their domestic legislation and legislative process. ${ }^{43}$

Such contextual approach will inevitably prioritize how environmental and social risks ought to be evaluated. Both the Bank and the client state share "complementary yet distinctive monitoring responsibilities" whose extent "is proportional to the Project's risks and impacts". ${ }^{44}$ As a result, the client state may have resort to the use of "strategic, sectoral or regional environmental and social assessments and cumulative impact assessments, where appropriate" and thus adopt a lower standard which the Bank ought to take into account when assessing the environmental and social risks and impacts. ${ }^{45}$ Nonetheless, this doesn't forsake the Bank to assume its own due diligence obligations when screening projects on their environment and social risks. Furthermore, it will hold the client state accountable for its compliance with the social and environmental obligations laid down in the legal agreements of the project and may take corrective measures to redress the situation or take other contractual remedies in case of persistent failure. ${ }^{46}$ In case people that have been or will be affected negatively by the Bank's failure to enforce its environmental and social policies, they could also seek redress and file complaints with the Bank's oversight mechanisms. ${ }^{47}$

While balancing between the sovereign environmental and social assessment standards and its own procedures towards integrating the sustainable development goals in its operational and financial policies, the Bank had established an Environmental and Social Exclusion List under its Environmental and Social Framework. In this respect, the Bank would not knowingly finance development projects that involve forced/child labour; production/trade in PCBs; production/ trade in "pharmaceuticals, pesticides/herbicides and other hazardous substances" which are banned or ought to be phased-out by the 1998 Rotterdam Convention on the Prior Informed Consent Procedure for Certain Hazardous Chemicals and Pesticides in International Trade and the 2001 Stockholm Convention on Persistent Organic Pollutants; production/trade in "ozone depleting substances" to be phased-out according to the 1987 Montreal Protocol on Substances that Deplete the Ozone Layer; "trade in wildlife or production of, or trade in, wildlife products regulated under the 1973 Convention on International Trade in Endangered Species

\footnotetext{
${ }^{43}$ Ibid., para 15 .

${ }^{44}$ Ibid., para 62.

${ }^{45} \mathrm{Ibid}$., para 67; Environmental and Social Standard 1, para 4A.

${ }^{46}$ Ibid., para 65-66.

${ }^{47}$ Ibid., para 64 .
} 
of Wild Fauna and Flora"; production/trade in weapons and ammunition; production/trade in alcoholic beverages except wine and beer; production/trade in tobacco; production/trade in asbestos; production/trade in wood from "sustainably managed forests"; "commercial logging operations or the purchase of logging equipment for use in primary tropical moist forests or old-growth forests"; transboundary movements of waste prohibited by the 1989 Basel Convention on the Control of Transboundary Movements of Hazardous Wastes and Their Disposal; "gambling, casinos and equivalent enterprises"; activities prohibited by national law or in violation of the 1979 Bonn Convention on the Conservation of Migratory Species of Wild Animals, 1971 Ramsar Convention on Wetlands, 1972 World Heritage Convention and 1992 Convention on Biological Diversity; damaging "marine and coastal fishing practices" and especially of "vulnerable and protected species".

As stipulated in Article 1 of the Articles of Agreement, the AIIB would cooperate with other multilateral development banks whose human rights practice may equally inform the operational and financial policies of the Bank. In this regard, the Bank has already in its early projects co-financed at least four infrastructure projects in transport and energy sectors in three different nations, namely with the World Bank for Indonesia's National Slum Upgrading Project ${ }^{48}$ and for Pakistan's Tarbela 5 Hydropower Extension Project; ${ }^{49}$ with the World Bank, the Asian Development Bank, the European Bank for Reconstruction and Development and the European Investment Bank for Azerbaijan's Trans-Anatolian Natural Gas Pipeline Project (TANAP) ${ }^{50}$ and with the Asian Development Bank for Pakistan's National Motorway M-4 Project. ${ }^{51}$ Such kind of cooperation can inform the development of national and regional environmental and social standards that can enhance the normativity of international human and environmental rights within Asia in the long-term.

\section{Conclusion}

The rise of Asia and its emerging economies - China in particular - has dramatically changed the geopolitical landscape of the 21 st century and will continue to dictate how their relationship with the West and other developed nations will evolve. Not only politically, but also economically this relationship has undergone tremendous changes. Calls to reshape the international economic order are now finally coming to fruition. Fears that China will dominate such new international and economic and political order have persisted and have undermined to understand how trade and development can be supported and facilitated not only by global

\footnotetext{
${ }^{48}$ Aiib.org (2016b).

${ }^{49}$ Aiib.org (2016c).

${ }^{50}$ Aiib.org (2016d).

${ }^{51}$ Aiib.org (2016e).
} 
governance institutions but also by regional actors and entities including China's new multilateral development banks, such the New Development Bank and the AIIB. Moreover, the loss of power on behalf of Western developed countries through such regionalization and fragmentation of the old international economic order has equally reinforced their anxieties in respect of the norms that shall govern economic and political life in those new constellations and within regional settings. An erosion of environmental and social standards by China's new financial vehicles may further open the door for defeatism and a human rights fatigue within the minds of Western policy-makers.

Nonetheless, through its relational governance China has sought to maintain the interconnectivity between Asia and other regions - in spite of the multipolar rather than fragmented world order. From its point of view, the world is still and should stay globalized. Its political discourse of mutual benefit and common development aims to give it the legitimacy to shape the international economic order and gradually give content to the right to development that constitutes the latter's legal basis at the same time. While its operationalization leans more towards a collective dimension, over the course of time and in space, close collaboration-in accordance with the principle of sovereign equality-between the members of developed and developing nations within the AIIB could increase trust and confidence in the very processes that are aimed at negotiating socio-economic arrangements that will not only determine the nature of the right to development but also to the scope of their relationship and vis-à-vis outsiders too, such as other international and regional development banks - including the World Bank and the Asian Development Bank.

It is within such set of complex relationships and exchange between share- and stakeholders that cooperation will be indispensable to the discharge of mandates of the respective development banks to finance development projects in Asia and beyond. A genuine dialogue on the operational and financial policies that should guide the implementation of environmental and social standards must equally accept "new cultural and political perspectives" as Kishore Mahbubani would argue. 52 The normativity of international human and environmental rights depends on the evolution of the relationship between the mixed membership of the AIIB that underpins their creation, development and interpretation and application in the first place within a regional setting at a given moment in time. Therefore, according to TORNIL, the universalist v. relativist debate on human rights protection regarding China's new development banks in Asia can be transcended when taking the development of the relationship of the members of the banks rather than their competing interests as the starting point of the discussion-without a dialogue between them there can be no room to find a common understanding on human rights protection in the first place.

\footnotetext{
${ }^{52}$ Mahbubani (2008), p. 224.
} 


\section{References}

Abdenur AE (2015) The new multilateral development banks and the future of development: What role for the UN? The United Nations Centre for Policy Research, November 2015

Abdenur AE, Folly M (2015) The New Development Bank and the institutionalization of the BRICS. Revolutions 3:66-95

Aiib.org (2016a) Subscriptions and voting power of member countries. https://www.aiib.org/ en/about-aiib/who-we-are/membership-status/.content/index/_download/20160930035841674. pdf. Accessed 18 May 2017

Aiib.org (2016b) Indonesia: National Slum Upgrading Project. https://www.aiib.org/en/projects/ approved/2016/indonesia-national-slum.html. Accessed 18 May 2017

Aiib.org (2016c) Pakistan: Tarbela 5 Hydropower Extension Project. https://www.aiib.org/en/ projects/approved/2016/pakistan-tarbela-5.html. Accessed 18 May 2017

Aiib.org (2016d) Azerbaijan: Trans-Anatolian Natural Gas Pipeline Project (TANAP). https:// www.aiib.org/en/projects/approved/2016/trans-anatolian.html. Accessed 18 May 2017

Aiib.org (2016e) Pakistan: National Motorway M-4 Project https://www.aiib.org/en/projects/ approved/2016/pakistan-national-motorway.html. Accessed 18 May 2017

Aizawa M, Yang C (2010) Green credit, green stimulus, green revolution? China's mobilization of banks for environmental cleanup. J Environ Dev 19:119-144

Archarya A (2011) Norm subsidiarity and regional orders: sovereignty, regionalism, and rule-making in the third world. Int Stud Quart 55:95-123

Bai Y, Faure M, Liu J (2014) The role of China's banking sector in providing green finance. Duke Environ Law Policy Forum 24:105-106

Bob D (2015) Asian infrastructure Investment Bank: China as responsible stakeholder? Sasakawa Peace Foundation USA, Washington, DC

Bohoslavsky, JP (2015) (Independent Expert on the Effects of Foreign Debt) end of mission statement. United Nations Human Rights Report, UN Doc. A/HRC/31/60/Add. 1, 6 July

Brautigam D (2011) Chinese development aid in Africa: what, where, why, and how much? In: Golley J, Song L (eds) Rising China: global challenges and opportunities. ANU Press, Canberra, pp 203-222

Callaghan M, Hubbard P (2016) Asian Infrastructure Investment Bank: multilateralism on the Silk Road. China Econ J 9:116-139

Chen Y (2013) Be careful, BRICS Development Bank. Our world—brought to you by United Nations University, 22 July

Coalition for Human Rights in Development (2016) What you need to know about the BRICS New Development Bank. http://rightsindevelopment.org/wp-content/uploads/2015/08/BRICSNDB-Factsheet-Final-1.pdf. Accessed 18 May 2017

Cunliffe P (2007) Sovereignty and the politics of responsibility. In: Bickerton CJ, Cunliffe P, Gourevitch A (eds) Politics without sovereignty: a critique of contemporary international relations. University College London Press, London, pp 39-57

Etzioni A (2016) The Asian Infrastructure Investment Bank: a case study of multifaceted containment. Asian Perspect 40:173-196

European Political Strategy Centre (2015) The Asian infrastructure investment bank: a new multilateral financial institution or a vehicle for China's geostrategic goals. Presented at the European Commission: 1 EPSC Strategic Notes, Brussels, April 2015

Evans J (2016) China: new bank's projects should respect rights-member countries key to ensuring transparency, accountability. Human Rights Watch, 24 June

Griffith-Jones S (2012) South-South financial cooperation (7 background paper). Presented at the United Nations Conference on Trade and Development, Geneva, March 2012

Griffith-Jones S (2014) A BRICS Development Bank: a dream coming true? Presented at the United Nations Conference on Trade and Development: 215 Discussion Papers, Geneva, March 2014 
Griffith-Jones S (2015) Financing global development: the BRICS New Development Bank. Presented at the United Nations Conference on Financing for Development in Addis-Ababa, the German Development Institute: 13 Briefing Paper, Bonn, 12-16 July 2015

Imf.org (2016) Review of the Special Drawing Right (SDR) currency basket. https://www.imf.org/ en/About/Factsheets/Sheets/2016/08/02/19/35/Review-of-the-Special-Drawing-Right-SDR-

Currency-Basket. Accessed 18 May 2017

Ingram J, Poon D (2013) BRICS: a new international economic order. Opinion: The North-South Institute, Ottawa

International Division of Ministry of Finance (2011) Promotion of the reform program of voting power in the World Bank made the rising power of developing countries. China State Finance Magazine, Finance Yearbook of China, pp 132-133

Ito T (2015) The future of the Asian Infrastructure Investment Bank: concerns for transparency and governance. 72 Occasional Paper Series, June 2015, Center on Japanese Economy and Business, Columbia Business School

Jin L (2015) Asia Investment Bank: Win-Win new solution. Liberation, 16 April

Lagon MP, Nowakowski A (2015) Banking on autocracy: Chinese-led bodies distort development. Freedom House, 17 August

Mahbubani K (2008) The New Asian hemisphere: the irresistible shift of global power to the east. Public Affairs, New York

Ndb.int (2016) NDB Factsheet. http://ndb.int/pdf/NDB-Fact-Sheet.pdf. Accessed 18 May 2017

People's Republic of China (2011) White paper on China's peaceful development. Information Office of the State Council, September 2011

People's Republic of China, Chinese National Development and Reform Commission, Ministry of Foreign Affairs, and Ministry of Commerce (2015) Vision and Actions on Jointly Building Silk Road Economic Belt and 21st-Century Maritime Silk Road. Information Office of the State Council, March 2015

People's Republic of China, Ministry of Foreign Affairs (2006) South-South development. http:// www.fmprc.gov.cn/web/ziliao_674904/tytj_674911/zcwj_674915/t24777.shtml. Accessed 18 May 2017

Qin Y (2010) International society as a process: institutions, identities, and China's peaceful rise. Chin J Int Polit 3:129-153

Qin Y (2011) Rule, rules, and relations: towards a synthetic approach to governance. Chin J Int Polit 4:117-145

Renard T (2015) The Asian Infrastructure Investment Bank (AIIB): China's new multilateralism and the erosion of the west. 63 Security Policy Brief

Rosenzweig J (2016) The AIIB and human rights: transparency will be the key to ensuring the Chinese-led International Bank supports human rights. The Diplomat, 24 June

Ruskola T (2013) Legal orientalism: China, the United States, and modern law. Harvard University Press, Cambridge

Schablizki J (2014) The BRICS Development Bank: A New Tool for South-South cooperation. 5 BPC Policy Brief

Sharda J (2016) The New Development Bank: its role in achieving BRICS renewable energy targets. Institute for Energy Economics and Financial Analysis, Cleveland

Subacchi P (2015) The AIIB is a threat to global economic governance. Foreign Policy, 31 March

The Economist (2017) China's beleaguered liberals: the two faces of Mr Xi, 18 February

United Nations (2015) The Millennium Development Goals Report. UN, New York

United Nations Human Rights (2011) UN Guiding Principles on Foreign Debt and Human Rights, UN Doc. A/HRC/20/23, New York, UN

Vanhullebusch M (2014) Searching for human rights: free trade agreements in Asia. In: Hu J, Vanhullebusch M (eds) Regional cooperation and free trade agreements in Asia. Brill/Nijhoff, Leiden/Boston, pp 219-245

Vanhullebusch M (2016a) Governing asymmetries on the battlefield: towards a relational normativity. Chin J Int Polit 9:307-348 
Vanhullebusch M (2016b) Finance, rule of law and human rights in China. In: $\mathrm{Hu}$ J, Vanhullebusch M, Harding A (eds) Finance, rule of law and development in Asia: perspectives from Singapore. Hong Kong and Mainland China, Brill/Nijhoff, Leiden/Boston, pp 168-194

Volcovici V, Wong SL (2011) Trumps wins open way for China to take climate leadership role. http://www.reuters.com/article/us-usa-election-climatechange-idUSKBN1360DK. Accessed 18 May 2017

Wan M (2016) The Asian Infrastructure Investment Bank: the construction of power and the struggle for the East Asian International Order. Palgrave Macmillan, New York

Weforum.org (2017) Speech of President Xi Jinping at the World Economic Forum Annual Meeting. https://www.weforum.org/events/world-economic-forum-annual-meeting-2017/ sessions/opening-plenary-davos-2017. Accessed 18 May 2017

Worldbank.org (2010) World Bank Group voice reform: enhancing voice and participation of developing and transition countries in 2010 and beyond. http://siteresources.worldbank.org/ DEVCOMMINT/Documentation/22553921/DC2010-006(E)Voice.pdf. Accessed 18 May 2017

Worldbank.org (2017) Subscriptions and voting power of member countries. http://siteresources. worldbank.org/BODINT/Resources/278027-1215524804501/IBRDCountryVotingTable.pdf. Accessed 18 May 2017

Xi J (2014) The Governance of China. Foreign Languages Press, Beijing

Xie X (2008) Governors' statements: People's Republic of China. Presented at the 41st Annual Meeting of the ADB Board of Governors, 5-6 May 2008. http://www.adb.org/publications/ summary-proceedings-41st-annual-meeting-board-governors. Accessed 18 May 2017

Zeng L (2016) Conceptual analysis of China's belt and road initiative: a road towards a regional community of common destiny. Chin J Int Law 15:517-541

\section{Author Biography}

Matthias Vanhullebusch (PhD, SOAS, University of London) is associate professor, executive director of the Asian Law Center, and KoGuan Youth Legal Scholar at the KoGuan Law School of the Shanghai Jiao Tong University since 2012. He has an expertise in Humanitarian Law and Policy, the Middle East, East Asia and Peacekeeping. He is the Managing Editor of the Asian Journal of Law and Society (CUP) and the Series Editor of Brill's Asian Law Series (Brill/Nijhoff) and Routledge Studies on Asia in the World (Taylor \& Francis). He has contributed to research projects at the Centre for Law and Conflict (SOAS), the Centre for International Studies and Diplomacy (SOAS), the Committee on Islamic Law and International Law of the International Law Association, EIUC, the Afghanistan Analysts Network, and the International Society for Military Law and the Law of War. He guest-lectured International Human Rights Law at SOAS, Public International Law at the University of Pretoria, and International Humanitarian Law for the ICRC at the Handong Global University, University of the Philippines, Korea University and in Hiroshima. He is co-editor-in-chief of the book Finance, Rule of Law and Development in Asia (Brill/Nijhoff, 2016). 
Open Access This chapter is licensed under the terms of the Creative Commons Attribution-NonCommercial-NoDerivatives 4.0 International License (http://creativecommons. org/licenses/by-nc-nd/4.0/), which permits any noncommercial use, sharing, distribution and reproduction in any medium or format, as long as you give appropriate credit to the original author (s) and the source, provide a link to the Creative Commons license and indicate if you modified the licensed material. You do not have permission under this license to share adapted material derived from this chapter or parts of it.

The images or other third party material in this chapter are included in the chapter's Creative Commons license, unless indicated otherwise in a credit line to the material. If material is not included in the chapter's Creative Commons license and your intended use is not permitted by statutory regulation or exceeds the permitted use, you will need to obtain permission directly from the copyright holder.

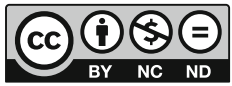

